\title{
The role of bosutinib in the treatment of chronic myeloid leukemia
}

\author{
Carlo Gambacorti-Passerini*,1, Philipp le Coutre ${ }^{2,3}$ \& Rocco Piazza1 \\ ${ }^{1}$ Department of Medicine \& Surgery, University of Milano-Bicocca, Italy \\ ${ }^{2}$ Charité-Universitätsmedizin Berlin, Corporate member of Freie Universität Berlin, Humboldt-Universität zuBerlin, Germany \\ ${ }^{3}$ Berlin Institute of Health, Department of Hematology, Oncology, and Tumor Immunology, Berlin, Germany \\ *Author for correspondence: carlo.gambacorti@unimib.it
}

The availability of several $B C R-A B L 1$ tyrosine kinase inhibitor (TKI) options means physicians and patients can select the most appropriate treatment for a patient with chronic myeloid leukemia (CML). BCR-ABL TKI selection as a first- or later-line therapy is dependent on a number of clinical factors. Regular monitoring of patients, patient education, dose optimization and management of treatment-emergent adverse events are key aspects of long-term chronic myeloid leukemia management and contribute to improved clinical outcomes, quality of life, patient adherence and healthcare costs. This review provides an overview of the $B C R-A B L 1$ TKI bosutinib, its pharmacology and clinical trials; discusses the impact of comorbidities and concomitant medications on bosutinib treatment selection; and suggests strategies for managing adverse events and dose optimization during bosutinib treatment.

First draft submitted: 10 September 2019; Accepted for publication: 15 November 2019; Published online: 13 December 2019

Keywords: bosutinib $\bullet$ chronic myeloid leukemia $\bullet$ first-line $\bullet$ later-line $\bullet$ treatment selection

\section{Introduction to chronic myeloid leukemia}

Chronic myeloid leukemia (CML) is a myeloproliferative neoplasm defined by the presence of the Philadelphia $(\mathrm{Ph})$ chromosome. CML is most frequently diagnosed among people aged 65-74 years, and has a 5-year survival rate of $69.2 \%$ [1]. CML can be classified into three stages: chronic phase (CP), accelerated phase (AP) and blast phase (BP) [1-5]. Without treatment, CP CML will progress to AP CML in 3-5 years [3,6].

Until 2000, treatment for CML was limited to hematopoietic stem cell transplant (HSCT) or treatment with busulfan, hydroxyurea or IFN- $\alpha$. The development of $B C R-A B L 1$-targeting tyrosine kinase inhibitors (TKIs) for the treatment of CML has revolutionized the treatment of this disease [2-4,7-10]. Imatinib (Glivec ${ }^{\circledR} /$ Gleevec $^{\circledR}$ ) was the first $B C R-A B L 1$-targeting TKI, which was approved for CML in 2001 by both the US FDA and the EMA $[11,12]$. This was followed by dasatinib $\left(\right.$ Sprycel ${ }^{\circledR}$ ), which in 2006 was the first second-generation $B C R-A B L 1$ TKI approved for CML (by both FDA and EMA) [13,14]. Nilotinib (Tasigna ${ }^{\circledR}$ ), another second-generation $B C R$ $A B L 1$ TKI, was approved for CML in 2007 (by both FDA and EMA) [15,16], followed by bosutinib (Bosulif ${ }^{\circledR}$ ), which received approval in 2012 by the FDA and in 2013 by the EMA [17,18]. A third-generation BCR-ABL1 TKI, ponatinib (Iclusig ${ }^{\circledR}$ ), was also approved for CML in 2012 by the FDA and in 2013 by the EMA [19,20]. The availability of imatinib and other $B C R-A B L 1$ TKIs allowed the prognosis of patients with CML to progressively ameliorate up to a normal life expectancy [21,22].

Current treatment options for adult patients with newly diagnosed (i.e., first-line) $\mathrm{CP} \mathrm{Ph}+\mathrm{CML}$ are imatinib, dasatinib, nilotinib and bosutinib [11-18]. Imatinib is also approved for the treatment of patients with $\mathrm{Ph}+\mathrm{CML}$ in $\mathrm{BP}, \mathrm{AP}$ or in patients with CP CML after failure of IFN- $\alpha$ therapy [11,12]. Dasatinib, bosutinib and ponatinib are approved for patients with $\mathrm{CP}, \mathrm{AP}$ or $\mathrm{BP} \mathrm{Ph}+\mathrm{CML}$ with resistance or intolerance to prior therapy, including imatinib [13,14,17-20]. Nilotinib is approved for the treatment of patients with $\mathrm{CP}$ and $\mathrm{AP} \mathrm{Ph}+\mathrm{CML}$ who are resistant to or intolerant to prior therapy, including imatinib [15,16].

Given that there are now several $B C R-A B L 1$ TKI options available for patients with CML, the selection of firstand later-line therapy is dependent on a number of clinical and patient factors. This review discusses the role of bosutinib in the treatment of patients with CML. 


\section{Introduction to bosutinib}

Bosutinib (also known as SKI-606), has been shown to bind to the kinase domain of $B C R-A B L 1$. In murine myeloid cell lines, bosutinib also inhibited 16 of 18 imatinib-resistant forms of $B C R-A B L 1$ kinase [17,18,23-27]. The Src family kinases Src, Lyn and Hck, as well as platelet-derived growth factor (PDGF) receptor and c-Kit, have also been shown to be inhibitory targets of bosutinib [17,18,23-27].

In pharmacokinetic studies, bosutinib exhibited dose-proportional increases in area under the plasma concentration-time curve and maximum plasma concentration $\left(\mathrm{C}_{\max }\right)$ over the oral dose range of 200$800 \mathrm{mg}[17,18,28,29]$. Across different dose groups, median time to $\mathrm{C}_{\max }$ was $3.0-6.0 \mathrm{~h}$ [29]. The absolute bioavailability of a single oral dose of bosutinib $500 \mathrm{mg}$ was $34 \%$ in healthy volunteers $[17,18,29]$. Protein binding of bosutinib was $94 \%$ in vitro and $96 \%$ ex vivo, and was independent of concentration $[17,18,29]$. Following a single intravenous dose of bosutinib $120 \mathrm{mg}$, the mean (standard deviation [SD]) terminal phase elimination half-life $\left(\mathrm{t}_{1 / 2}\right)$ was 35.5 (8.5) $\mathrm{h}$ and the mean (SD) drug clearance (CL) was 63.6 (14.1) l/h [17,18,29]. Following a single oral dose of bosutinib in patients with CML, the mean (SD) $\mathrm{t}_{1 / 2}$ was 22.5 (1.7) $\mathrm{h}$, and the mean (SD) CL was $189(48) \mathrm{l} / \mathrm{h}[17,18,29]$. Bosutinib undergoes predominantly hepatic metabolism in humans and is primarily metabolized by cytochrome P450 (CYP) 3A4. More than $90 \%$ of bosutinib is excreted in the feces $[17,18,29]$.

In preclinical safety studies, treatment with bosutinib had no effect on respiratory function and blood pressure and no/minimal impact on cardiac function $[17,18]$. Bosutinib also has not demonstrated any mutagenic, carcinogenic, phototoxic or clastogenic potential $[17,18]$. Some reproductive and developmental toxicity, as well as fertility impairment, was reported during bosutinib treatment in preclinical animal studies conducted in rats and rabbits $[17,18]$. In fertility studies, a slight decrease in fertility was observed in male rats; increased embryonic resorptions, and decreases in implantations and viable embryos were observed in female rats $[17,18]$.

Bosutinib $400 \mathrm{mg}$ once daily (QD) is approved for the treatment of patients with newly diagnosed $\mathrm{CP} \mathrm{Ph}+\mathrm{CML}$ and at $500 \mathrm{mg}$ QD in patients with $\mathrm{CP}, \mathrm{AP}$ or $\mathrm{BP} \mathrm{Ph}+\mathrm{CML}$ with resistance or intolerance to prior therapy $[17,18]$.

\section{Bosutinib as a first-line option for the treatment of CML}

Bosutinib $400 \mathrm{mg}$ QD is approved as first-line treatment in patients with newly diagnosed $\mathrm{CP} \mathrm{Ph}+\mathrm{CML}$ [17,18]. Two studies, BFORE and BELA, are pivotal Phase III trials of bosutinib in the first-line setting (Table 1). The BFORE trial investigated bosutinib $400 \mathrm{mg}$ QD compared with imatinib $400 \mathrm{mg}$ QD [30,31]. Results showed that patients who received bosutinib had significantly higher rates of major molecular response (MMR) at and complete cytogenetic response (CCyR) by 12 and 24 months, and achieved responses faster, compared with imatinib-treated patients, for example, MMR and CCyR rates at 12 months were 47 versus $37 \%$ and 77 versus $66 \%$ for bosutinib and imatinib, respectively [30,31]. The BELA trial investigated first-line bosutinib $500 \mathrm{mg}$ QD versus imatinib $400 \mathrm{mg}$ QD [32-35]. The BELA trial did not meet its primary end point of CCyR at 12 months (70 vs 68\%), despite a higher MMR rate (41 vs 27\%), faster times to CCyR and MMR, and a trend toward fewer on-treatment transformations to AP/BP with bosutinib versus imatinib [32-35]. This negative result was probably due to multiple factors: the higher dose administered, resulting in high rates of dose interruptions (61 vs $42 \%$ ) and discontinuations (19 vs 6\%) in the bosutinib group compared with the imatinib group [32-35]. This was further compounded by a number of centers being relatively inexperienced in administering bosutinib. In both trials, the safety profile of bosutinib was consistent with previous reports and no new safety signals were identified [30-35].

Bosutinib has not been directly compared with IFN- $\alpha$, dasatinib or nilotinib; however, these agents have been evaluated in comparison with imatinib in Phase III trials in the first-line setting. In the IRIS trial, patients administered imatinib had improved hematologic and cytogenetic responses compared with patients who received IFN- $\alpha[36,37]$. Both dasatinib $100 \mathrm{mg}$ QD and nilotinib 300 and $400 \mathrm{mg}$ twice-daily doses demonstrated significantly greater CCyR and MMR compared with imatinib $400 \mathrm{mg}$ QD in the DASISION and ENESTnd trials, respectively [38-41]. In terms of safety, although the $B C R-A B L$ TKIs share some common class-wide side effects and were generally well tolerated in their respective clinical trials, each agent has a distinct safety profile, discussed later in this review, that should be considered by clinicians during first-line treatment selection [30-41].

\section{Bosutinib in the setting of second- \& later-line CML treatment}

In patients with $\mathrm{CP}, \mathrm{AP}$ or $\mathrm{BP} \mathrm{Ph}+\mathrm{CML}$ with resistance or intolerance to prior therapy, the approved bosutinib dose is $500 \mathrm{mg}$ QD $[17,18]$. Key trials of bosutinib in the second- and later-line settings include a single-arm, Phase I/II trial and the Phase IV BYOND trial (Table 2). The Phase I/II trial was an open-label, multicenter study that evaluated bosutinib $500 \mathrm{mg}$ QD in patients with imatinib-resistant or -intolerant CML, with separate cohorts for 


\begin{tabular}{|c|c|c|c|c|c|}
\hline Trial & Treatment arms & Main efficacy findings & Main safety findings & $\begin{array}{l}\text { Long-term follow-up } \\
\text { efficacy data }\end{array}$ & $\begin{array}{l}\text { Long-term follow-up } \\
\text { safety data }\end{array}$ \\
\hline $\begin{array}{l}\text { Phase III BFORE trial in } \\
\text { patients with newly } \\
\text { diagnosed CP CML }[30,31]\end{array}$ & $\begin{array}{l}\text { - Bosutinib } \\
400 \text { mg QD } \\
\text { - Imatinib } \\
400 \text { mg QD }\end{array}$ & $\begin{array}{l}\text { MMR rate at } 12 \text { months: } \\
\text { - Bosutinib: } 47.2 \% \\
\text { - Imatinib: } 36.9 \% \\
\text { - } \mathrm{p}=0.02 \\
\text { CCyR rate by } 12 \text { months: } \\
\text { - Bosutinib: } 77.2 \% \\
\text { - Imatinib: } 66.4 \% \\
\text { - } \mathrm{p}=0.0075 \\
\text { 12-month survival rate: } \\
\text { - Bosutinib: } 99.6 \% \\
\text { - Imatinib: } 97.9 \% \\
\text { Dose escalations due to } \\
\text { suboptimal response: } \\
\text { - Bosutinib: } 17.2 \% \\
\text { - Imatinib: } 27.5 \%\end{array}$ & $\begin{array}{l}\text { Most common AEs with } \\
\text { bosutinib: } \\
\text { - Diarrhea: } 70.1 \% \\
\text { - Nausea: } 35.1 \% \\
\text { - Thrombocytopenia: } \\
35.1 \% \\
\text { Most common AEs with } \\
\text { imatinib: } \\
\text { - Nausea: } 38.5 \% \\
\text { - Diarrhea: } 33.6 \% \\
\text { - Muscle spasms: } 26.4 \% \\
\text { Discontinued treatment: } \\
\text { - Bosutinib: } 22.0 \% \\
\text { - Imatinib: } 26.8 \% \\
\text { Dose interruptions and } \\
\text { reductions due to AEs: } \\
\text { - Bosutinib: } 56.3 \% \\
\text { - Imatinib: } 35.8 \%\end{array}$ & $\begin{array}{l}\text { MMR by } 24 \text { months: } \\
\text { - Bosutinib: } 67.2 \% \\
\text { - Imatinib: } 57.5 \% \\
\text { - } p=0.02 \\
\text { Cumulative CCyR: } \\
\text { - Bosutinib: } 82.5 \% \\
\text { - Imatinib: } 76.8 \% \\
\text { - } p=0.113 \\
\text { OS at } 24 \text { months: } \\
\text { - Bosutinib: } 99.2 \% \\
\text { - Imatinib: } 97.0 \% \\
\text { Dose escalations due to } \\
\text { suboptimal response: } \\
\text { - Bosutinib: } 20.1 \% \\
\text { - Imatinib: } 30.9 \%\end{array}$ & $\begin{array}{l}\text { AEs related to study drug: } \\
\text { - Bosutinib: } 16.0 \% \\
\text { - Imatinib: } 9.8 \% \\
\text { Discontinued treatment: } \\
\text { - Bosutinib: } 29.1 \% \\
\text { - Imatinib: } 33.6 \% \\
\text { Dose delay due to AEs: } \\
\text { - Bosutinib: } 60.4 \% \\
\text { - Imatinib: } 38.9 \% \\
\text { Dose reductions due to } \\
\text { AEs: } \\
\text { - Bosutinib: } 40.3 \% \\
\text { - Imatinib: } 21.5 \%\end{array}$ \\
\hline $\begin{array}{l}\text { Phase III BELA trial in } \\
\text { patients with newly } \\
\text { diagnosed CP CML [32-35] }\end{array}$ & $\begin{array}{l}\text { - Bosutinib } \\
500 \mathrm{mg} \\
\text { QD } \\
\text { - Imatinib } \\
400 \mathrm{mg} \\
\text { QD }\end{array}$ & $\begin{array}{l}\text { CCyR rate at } 12 \text { months: } \\
\text { - Bosutinib: } 70 \% \\
\text { - Imatinib: } 68 \% \\
\text { - } p=0.601 \\
\text { MMR rate at } 12 \text { months: } \\
\text { - Bosutinib: } 41 \% \\
\text { - Imatinib: } 27 \% \\
\text { - } p<0.001 \\
\text { Confirmed CHR at } \\
12 \text { months: } \\
\text { - Bosutinib: } 71 \% \\
\text { - Imatinib: } 85 \% \\
\text { - p > } 0.999 \\
\text { OS at } 12 \text { months: } \\
\text { - Bosutinib: }>99 \% \\
\text { - Imatinib: } 97 \% \\
\text { Dose escalations due to } \\
\text { suboptimal response: } \\
\text { - Bosutinib: } 4 \% \\
\text { - Imatinib: } 12 \%\end{array}$ & $\begin{array}{l}\text { Most common AEs with } \\
\text { bosutinib: } \\
\text { - Anemia: } 81 \% \\
\text { - Diarrhea: } 68 \% \\
\text { - Thrombocytopenia: } \\
66 \% \\
\text { Most common AEs with } \\
\text { imatinib: } \\
\text { - Anemia: } 84 \% \\
\text { - Thrombocytopenia: } \\
63 \% \\
\text { - Hypophosphatemia: } \\
63 \% \\
\text { Discontinued treatment } \\
\text { due to AEs: } \\
\text { - Bosutinib: } 19 \% \\
\text { - Imatinib: } 6 \% \\
\text { Dose interruptions due to } \\
\text { AEs: } \\
\text { - Bosutinib: } 61 \% \\
\text { - Imatinib: } 42 \% \\
\text { Dose reductions due to } \\
\text { AEs: } \\
\text { - Bosutinib: } 39 \% \\
\text { - Imatinib: } 18 \%\end{array}$ & $\begin{array}{l}\text { Cumulative CCyR rate by } \\
24 \text { months: } \\
\text { - Bosutinib: } 79 \% \\
\text { - Imatinib: } 80 \% \\
\text { MMR rate at } 24 \mathrm{mo} \text { : } \\
\text { - Bosutinib: } 47 \% \\
\text { - Imatinib: } 41 \% \\
\text { Dose escalations due to } \\
\text { suboptimal response: } \\
\text { - Bosutinib: } 6 \% \\
\text { - Imatinib: } 18 \% \\
\text { 24-month survival rate: } \\
\text { - Bosutinib: } 97 \% \\
\text { - Imatinib: } 95 \%\end{array}$ & $\begin{array}{l}\text { Discontinued treatment } \\
\text { due to AEs: } \\
\text { - Bosutinib: } 25 \% \\
\text { - Imatinib: } 9 \% \\
\text { Dose interruptions due to } \\
\text { AEs: } \\
\text { - Bosutinib: } 66 \% \\
\text { - Imatinib: } 45 \% \\
\text { Dose reductions due to } \\
\text { AEs: } \\
\text { - Bosutinib: } 43 \% \\
\text { - Imatinib: } 21 \%\end{array}$ \\
\hline
\end{tabular}

AE: Adverse event; CCyR: Complete cytogenetic response; CHR: Complete hematologic response; CML: Chronic myeloid leukemia; MMR: Major molecular response; OS: Overall survival; QD: Once daily.

$\mathrm{CP}, \mathrm{AP}$ and BP CML [42-47]. In this trial, bosutinib demonstrated durable efficacy and a manageable safety profile in patients with CML treated for up to 5 years [42-47]. The Phase IV BYOND trial of bosutinib $500 \mathrm{mg}$ QD included patients with CML after failure of prior TKI treatment and those who are otherwise not appropriate for treatment with other TKIs [48]. Patients treated with bosutinib showed high rates of cytogenetic and molecular responses, including a large proportion of patients who achieved deep molecular responses; in patients with $\mathrm{CP} P \mathrm{Ph}+\mathrm{CML}$, 81.3\% achieved CCyR and 71.8\% achieved MMR [48]. In both the Phase I/II trial and BYOND, treatment with bosutinib was tolerable and manageable; diarrhea and nausea were the most common adverse events (AEs) in both trials $[42-48]$.

In patients with imatinib-resistant or -intolerant CP CML, both dasatinib (Phase III trial, CA180-034) and nilotinib (Phase II trial) have reported long-term efficacy and acceptable safety profiles [49,50]. In the Phase II PACE trial, ponatinib demonstrated durable and clinically meaningful efficacy and acceptable tolerability in patients with imatinib-resistant or -intolerant CP CML [51]. There are no comparative trials for these BCR-ABL1 TKIs in the second- and later-line settings; however, in a matching-adjusted indirect comparison analysis in patients in second-line treatment of CP CML, both progression-free survival and overall survival were longer with bosutinib compared with either dasatinib or nilotinib [52]. Dasatinib and nilotinib reported numerically greater responses versus bosutinib for major cytogenetic response (MCyR) [52]. 
Table 2. Key trials of bosutinib in the second- and later-line settings of chronic myeloid leukemia.

\begin{tabular}{|c|c|c|c|c|c|}
\hline Trial & Treatment arms & Main efficacy findings & Main safety findings & $\begin{array}{l}\text { Long-term follow-up } \\
\text { efficacy data }\end{array}$ & $\begin{array}{l}\text { Long-term follow-up } \\
\text { safety data }\end{array}$ \\
\hline $\begin{array}{l}\text { Phase I/II open-label, } \\
\text { multicenter trial in } \\
\text { patients with } \\
\text { imatinib-resistant or } \\
\text { imatinib-intolerant CP } \\
\text { CML }[42,47]\end{array}$ & $\begin{array}{l}\text { - Bosutinib } \\
500 \mathrm{mg} \\
\text { QD }\end{array}$ & $\begin{array}{l}\text { MCyR at } 24 \text { wk: } \\
\text { - All patients: } 31 \% \\
\text { - Imatinib-resistant: } \\
33 \% \\
\text { - Imatinib-intolerant: } \\
27 \% \\
\text { Achieved MCyR during the } \\
\text { study: } 53 \% \\
\text { Achieved CCyR during the } \\
\text { study: } 41 \% \\
\text { OS at } 1 \text { yr: } 97 \% \\
\text { OS at } 2 \text { yr: } 92 \%\end{array}$ & $\begin{array}{l}\text { Most common } \\
\text { non-hematologic AEs: } \\
\text { - Diarrhea: } 84 \% \\
\text { - Nausea: } 44 \% \\
\text { - Rash: } 44 \% \\
\text { Discontinued treatment } \\
\text { due to AEs: } 21 \% \\
\text { Most common AEs leading } \\
\text { to discontinuation: } \\
\text { - Thrombocytopenia: } \\
4 \% \\
\text { - Increased ALT: } 2 \% \\
\text { - Increased AST: } 2 \% \\
\text { - Diarrhea: } 2 \% \\
\text { Dose interruptions due to } \\
\text { AEs: } \\
\text { - All patients: } 66 \% \\
\text { - Imatinib-resistant: } \\
61 \% \\
\text { - Imatinib-intolerant: } \\
77 \% \\
\text { Dose reductions due to } \\
\text { AEs: } \\
\text { - All patients: } 47 \% \\
\text { - Imatinib-resistant: } \\
43 \% \\
\text { - Imatinib-intolerant: } \\
56 \%\end{array}$ & $\begin{array}{l}\text { Cumulative MCyR rate: } \\
\text { - Week 12: } 35 \% \\
\text { - Year 2: } 58 \% \\
\text { - Year 5: } 60 \% \\
\text { Cumulative CCyR rate: } \\
\text { - Week 12: } 22 \% \\
\text { - Year 2: } 46 \% \\
\text { - Year 5: } 50 \% \\
\text { Cumulative MMR rate: } \\
42 \% \\
\text { Probability of OS at year 2: } \\
91 \% \\
\text { Probability of OS at year 5: } \\
\text { 84\% } \\
\text { Discontinued treatment: } \\
\text { - By year 2: } 46 \% \\
\text { - Years 3-5: } 13 \%\end{array}$ & $\begin{array}{l}\text { Discontinued treatment } \\
\text { due to AEs: } 24 \% \\
\text { Most common } \\
\text { hematologic AEs: } \\
\text { - Thrombocytopenia: } \\
42 \% \\
\text { - Anemia: } 29 \% \\
\text { - Neutropenia: } 16 \% \\
\text { Most common } \\
\text { non-hematologic AEs: } \\
\text { - Diarrhea: } 86 \% \\
\text { - Nausea: } 46 \% \\
\text { - Vomiting: } 37 \%\end{array}$ \\
\hline $\begin{array}{l}\text { Phase IV BYOND trial in } \\
\text { patients with CML and } \\
\text { resistance/intolerance to } \\
\text { prior treatment [48] }\end{array}$ & $\begin{array}{l}\text { - Bosutinib } \\
500 \mathrm{mg} \\
\text { QD }\end{array}$ & $\begin{array}{l}\text { Cumulative confirmed } \\
\text { MCyR by } 1 \text { year in patients } \\
\text { with CP Ph+CML: } 75.8 \% \\
\text { Cumulative confirmed } \\
\text { OHR response by } 1 \text { year in } \\
\text { patients with AP CML: } \\
75.0 \% \\
\text { Cumulative CCyR in } \\
\text { patients with CP Ph+CML: } \\
81.3 \% \\
\text { Cumulative MMR in } \\
\text { patients with CP Ph+CML: } \\
71.8 \% \\
\text { OS in patients with CP Ph+ } \\
\text { CML: } \\
\text { At } 1 \text { year: } 98.0 \% \\
\text { At } 2 \text { year } 96.0 \%\end{array}$ & $\begin{array}{l}\text { Discontinued treatment } \\
\text { due to AEs in patients } \\
\text { with CP Ph+ CML: } 25.0 \% \\
\text { Most common AEs in the } \\
\text { overall patient population: } \\
\text { - Diarrhea: } 87.7 \% \\
\text { - Nausea: } 39.9 \% \\
\text { - Vomiting: } 32.5 \% \\
\text { Grade } 3 / 4 \mathrm{AEs} \text { occurring in } \\
>10 \% \text { of patients in the } \\
\text { overall patient population: } \\
\text { - Diarrhea: } 16.0 \% \\
\text { - Increased ALT: } 14.1 \% \\
\text { Dose reductions due to } \\
\text { AEs in patients with CP } \\
\text { Ph+ CML: } 78.2 \% \\
\text { Dose delays due to AEs in } \\
\text { patients with CP Ph+ CML: } \\
75.6 \%\end{array}$ & Ongoing & Ongoing \\
\hline
\end{tabular}

AE: Adverse event; ALT: Alanine aminotransferase; AP: Accelerated phase; AST: Aspartate aminotransferase; CCyR: Complete cytogenetic response; CHR: Complete hematologic response; CML: Chronic myeloid leukemia; CP: Chronic phase; MCyR: Major cytogenetic response; MMR: Major molecular response; OS: Overall survival; Ph: Philadelphia chromosome; QD: Once daily.

\section{General considerations for bosutinib treatment selection in CML Disease risk}

Disease risk status is a consideration for treatment selection in newly diagnosed patients with CP CML. Currently, there are three prognostic scoring systems utilized in clinical practice: Sokal, Hasford (Euro) and European Treatment and Outcome Study (EUTOS) [2-4,9,53-56]. These scoring systems use clinical parameters to predict outcomes, for example, the EUTOS score is based on spleen size and the percentage of basophils in the blood, whereas the Sokal and Hasford scores include a number of factors, such as spleen size, age, peripheral blood blasts and platelet count [2-4,9,53-56]. Patients with low-risk scores are likely to respond to treatment with any BCR-ABL1 TKI, whereas a second-generation TKI, such as bosutinib, dasatinib or nilotinib, might be preferable in patients with intermediate or high-risk scores [2-4,9,53-56]. However, no controlled study has demonstrated a significant decrease in progression to $\mathrm{AP} / \mathrm{BP}$ in patients receiving a second-generation $B C R-A B L 1$ TKI compared with imatinib [57]. 


\section{Comorbidities \& concomitant medications}

The number of patients with comorbid conditions in clinical trials is typically low and/or patients with certain conditions are excluded from entering the trial. This is in contrast to clinical practice, where many patients will present with comorbid conditions and receive concomitant medications; conditions may also arise during their therapy plan that require supportive care to manage the disease. These factors can have a large impact on the selection of treatments for first-, second- and later-line CML, including treatment with bosutinib (Table 3) [2-4,9,58-61].

In patients with a low number of cardiovascular risk factors, any $B C R-A B L 1$ TKI can be administered. Bosutinib, as well as imatinib and dasatinib, is generally recommended in patients with a higher number of cardiac or vascular risk factors or comorbidities, for example, patients with history of arrhythmias, poorly controlled hypertension, peripheral arterial occlusive disease or heart disease $[2,3,8,9,58,60,62-65,67-70]$. However, bosutinib should be used with caution in patients receiving agents that have the potential to prolong the corrected QT (QTc) interval, for example, anti-arrhythmic medications or others such as chloroquine, clarithromycin, domperidone and methadone $[17,18]$.

In patients with pulmonary comorbidities or a history of lung disease, such as chronic obstructive pulmonary disease, bosutinib is generally associated with a lower risk of pulmonary AEs compared with dasatinib; therefore, bosutinib is recommended, as are imatinib, nilotinib and ponatinib, in these patients $[2,3,8,9,60,63,65]$. Additionally, bosutinib may also be preferable in patients at risk of developing pleural effusions, pulmonary arterial hypertension or pneumonitis $[2,3,8,9,60,63,65]$. However, fluid retention has been reported, although rarely, during bosutinib treatment, and may manifest as pericardial effusion, pleural effusion, pulmonary edema and/or peripheral edema; therefore, patients should be monitored for these symptoms and managed using supportive care and/or modification to a bosutinib therapy plan, where necessary $[17,18]$.

In patients with diabetes or hyperglycemia, bosutinib is recommended, as are imatinib and dasatinib, but should be used with caution in patients with pancreatitis or a history of pancreatitis $[3,8,17,18,60,63,65]$. Elevations in serum transaminases have been reported during treatment with bosutinib; therefore, bosutinib should be used with caution in patients with hepatic comorbidities. All BCR-ABL1 TKIs are predominantly metabolized via the CYP system; therefore, concomitant administration of bosutinib with CYP3A 4 inhibitors and inducers should be avoided, where possible $[3,8,17,18,63,65]$. In patients with hepatic or renal impairment, bosutinib dose reductions are recommended, as well as periodic monitoring during treatment $[17,18]$.

Bosutinib should be used with caution in patients with gastrointestinal comorbidities, in particular patients with diarrhea, chronic inflammatory bowel disease or gastric ulcer $[3,8,17,18,63,65]$. Common AEs during treatment with bosutinib include diarrhea, nausea, vomiting and abdominal pain; therefore, patients should be regularly monitored and supportive care administered, where necessary. Additionally, concomitant administration of bosutinib with proton pump inhibitors (PPIs) decreased bosutinib exposure compared with bosutinib alone, and may lead to reduced efficacy. Therefore, co-administration of bosutinib with PPIs should be avoided, and replaced with shortacting antacids or $\mathrm{H} 2$ antagonists. The administration times of short-acting antacids/ $\mathrm{H} 2$ antagonists and bosutinib should also be separated, where possible $[3,8,17,18,58,63,65]$.

In preclinical studies, congenital abnormalities and reproductive toxicity were reported during bosutinib treatment in female animals. There were also reports of a risk in decreased fertility in male animals $[17,18]$. However, a review of pregnancy outcomes in patients with CML treated with bosutinib reported the number of spontaneous abortions and malformations were within the range for normal pregnancies, and that there were no specific bosutinib-induced abnormalities [71]. However, treatment with bosutinib is not recommended at any time during pregnancy $[17,18]$. It is not yet known if bosutinib and/or its metabolites are excreted in human milk, and breastfeeding should be discontinued during treatment with bosutinib $[17,18]$. Prior to starting bosutinib treatment, female patients with CML should receive a pregnancy test. Contraceptive use is recommended for female patients during treatment and for $\geq 1$ month after the last dose of bosutinib. There are currently no restrictions for male patients with CML; however, males and their female partners should be made aware of the potential risks associated with bosutinib during pregnancy $[17,18]$.

\section{Management of AEs}

The introduction of $B C R-A B L 1$ TKIs has led to a shift in the treatment goals for CML. In many cases, CP CML has transformed from a terminal disease to a long-term chronic condition. Therefore, one of the biggest challenges in long-term therapy plans is monitoring and managing treatment-emergent AEs [2,8,72,73]. Effective AE monitoring and management can lead to improved clinical outcomes, quality of life and treatment adherence [3,56,65,70,72,74]. Careful consideration of the patient's medical history, risk factors, pre-existing comorbidities and concomitant 
Table 3. Summary of bosutinib use in patients with concomitant medications, comorbidities or other special populations.

\begin{tabular}{|c|c|}
\hline Parameter & Use of bosutinib \\
\hline Dosing and administration & $\begin{array}{l}\text { - } 400 \mathrm{mg} \text { QD with food in newly diagnosed patients with CP Ph+ CML } \\
\text { - } 500 \mathrm{mg} \text { QD with food in CP, AP or BP Ph+ CML with resistance or intolerance to prior therapy }\end{array}$ \\
\hline \multicolumn{2}{|l|}{ Concomitant medications } \\
\hline Antacids, $\mathrm{H} 2$ antagonists, PPIs & $\begin{array}{l}\text { - Use short-acting antacids or } \mathrm{H} 2 \text { antagonists as alternative to PPIs } \\
\text { - Separate administration times, i.e., take bosutinib in the morning and antacids/H2 antagonists in the } \\
\text { evening, whenever possible }\end{array}$ \\
\hline CYP substrates, inhibitors and inducers & $\begin{array}{l}\text { - Co-administration of CYP3A4 inhibitors and inducers should be avoided } \\
\text { - If concomitant use of CYP3A4 inhibitors and inducers is necessary, consider dose reductions or } \\
\text { interruptions }\end{array}$ \\
\hline QTc prolonging agents & $\begin{array}{l}\text { - Use with caution in patients taking anti-arrhythmic medications or products such as chloroquine, } \\
\text { clarithromycin, domperidone, halofantrine, haloperidol, methadone and moxifloxacin }\end{array}$ \\
\hline \multicolumn{2}{|c|}{ Comorbidities and other special populations } \\
\hline CV comorbidities & $\begin{array}{l}\text { - Generally lower risk of CV AEs; therefore, recommended alongside imatinib and dasatinib } \\
\text { - However, CV risk factors should be assessed and a baseline ECG performed prior to treatment initiation } \\
\text { - Correct hypokalemia or hypomagnesemia prior to treatment and regularly monitor during treatment }\end{array}$ \\
\hline Pulmonary comorbidities & $\begin{array}{l}\text { - Generally lower risk of pulmonary AEs; therefore, recommendable alongside imatinib, nilotinib and } \\
\text { ponatinib } \\
\text { - Fluid retention may manifest as pleural effusion and/or pulmonary edema } \\
\text { - In cases of pleural effusion and/or pulmonary edema, monitor patients and manage using standard of } \\
\text { care treatment. Consider withholding bosutinib, or dose reductions or discontinuations }\end{array}$ \\
\hline Pancreatitis and diabetes & $\begin{array}{l}\text { - In patients with diabetes, bosutinib is recommended, as is imatinib and dasatinib } \\
\text { - In patients with pancreatitis or a history of pancreatitis, bosutinib should be used with caution }\end{array}$ \\
\hline Gastrointestinal comorbidities & $\begin{array}{l}\text { - Diarrhea, nausea, vomiting and abdominal pain have been reported during bosutinib treatment } \\
\text { - Bosutinib should be used with caution in patients with diarrhea, chronic inflammatory bowel disease or } \\
\text { gastric ulcer } \\
\text { - Monitor and manage patients, as necessary, using standards of care } \\
\text { - Consider dose reductions or discontinuations }\end{array}$ \\
\hline Hepatic comorbidities & $\begin{array}{l}\text { - Elevations in serum transaminases have been reported during bosutinib treatment } \\
\text { - In patients with liver disease or a history of liver disease, bosutinib should be used with caution } \\
\text { - Monitor liver enzymes at least monthly for the first } 3 \text { months and where necessary } \\
\text { - Consider withholding bosutinib, or dose reductions or discontinuations }\end{array}$ \\
\hline Hepatic impairment & $\begin{array}{l}\text { In newly diagnosed patients with } \mathrm{CP} P \mathrm{Ph}+\mathrm{CML} \text { or } \mathrm{CP} \text {, } \mathrm{AP} \text { or } \mathrm{BP} \mathrm{Ph}+\mathrm{CML} \text { with resistance or intolerance to } \\
\text { prior therapy: } \\
\text { - Mild (Child-Pugh A), moderate (Child-Pugh B) or severe (Child-Pugh C) hepatic impairment: dose } \\
\text { reduction to } 200 \mathrm{mg} \text { QD }\end{array}$ \\
\hline Fluid retention & $\begin{array}{l}\text { - Fluid retention has been reported during bosutinib treatment, and may manifest as pericardial effusion, } \\
\text { pleural effusion, pulmonary edema and/or peripheral edema } \\
\text { - Monitor patients and manage using standard of care treatment } \\
\text { - Consider withholding bosutinib, or dose reductions or discontinuations }\end{array}$ \\
\hline Renal impairment & $\begin{array}{l}\text { - Monitor renal function at baseline and during treatment with bosutinib, in particular, for those patients } \\
\text { who have pre-existing renal impairment or risk factors for renal dysfunction, including concomitant use of } \\
\text { medications with the potential for nephrotoxicity, e.g., diuretics, ACE inhibitors, angiotensin receptor } \\
\text { blockers and NSAIDs } \\
\text { Newly diagnosed patients with } \mathrm{CP} P \mathrm{Ph}+\mathrm{CML} \text { : } \\
\text { - } \mathrm{Cr}_{\mathrm{CL}}: 30-50 \mathrm{~mL} / \mathrm{min} \text { : dose reduction to } 300 \mathrm{mg} \mathrm{QD} \\
\text { - } \mathrm{Cr}_{\mathrm{CL}}:<30 \mathrm{~mL} / \mathrm{min} \text { : dose reduction to } 200 \mathrm{mg} \mathrm{QD} \\
\mathrm{CP}, \mathrm{AP}_{\text {, or }} \mathrm{BP} \mathrm{Ph}+\mathrm{CML} \text { with resistance or intolerance to prior therapy: } \\
\text { - } \mathrm{Cr}_{\mathrm{CL}}: 30-50 \mathrm{~mL} / \mathrm{min} \text { : dose reduction to } 400 \mathrm{mg} \mathrm{QD} \\
\text { - } \mathrm{Cr}_{\mathrm{CL}}:<30 \mathrm{~mL} / \mathrm{min} \text { : dose reduction to } 300 \mathrm{mg} \mathrm{QD}\end{array}$ \\
\hline Pregnancy & $\begin{array}{l}\text { - Female patients should receive a pregnancy test prior to starting bosutinib treatment, and use } \\
\text { contraception during treatment and for } \geq 1 \text { month after the last dose } \\
\text { - There are currently no restrictions for male patients } \\
\text { - If pregnancy occurs, both male and female patients should be warned of the potential hazard to the } \\
\text { fetus and to discuss risks versus benefits with the healthcare provider }\end{array}$ \\
\hline \multicolumn{2}{|c|}{$\begin{array}{l}\text { ACE: Angiotensin-converting enzyme; AE: Adverse event; AP: Accelerated phase; BP: Blast phase; CML: Chronic myeloid leukemia; CP: Chronic phase; CrCL: Creatinine clearance; } \\
\text { CV: Cardiovascular; CYP: Cytochrome P450; ECG: Electrocardiogram; H2: Histamine } 2 \text { receptor; NSAID: Nonsteroidal anti-inflammatory drug; Ph: Philadelphia chromosome; PPI: } \\
\text { Proton pump inhibitor; QD: Once daily; QTC: Corrected QT interval. } \\
\text { Data taken from }[2,3,7,9,17,18,56,59,60,62-66] \text {. }\end{array}$} \\
\hline
\end{tabular}


Table 4. Summary of common adverse events associated with bosutinib treatment and management strategies.

\begin{tabular}{|c|c|}
\hline Common AEs & AE management strategies \\
\hline $\begin{array}{l}\text { Gastrointestinal toxicities: } \\
\text { - Nausea } \\
\text { - Diarrhea } \\
\text { - Vomiting }\end{array}$ & $\begin{array}{l}\text { - Take with food and/or water per label instructions } \\
\text { - Concomitant administration of anti-nausea, anti-diarrheal, anti-emetic medications and/or fluid replacement } \\
\text { - Avoid large meals, alcohol, caffeine, lactose-containing products, laxatives/stool softeners, raw fruits and } \\
\text { vegetables, and sweet, spicy or fatty foods } \\
\text { - Avoid concomitant use of PPIs } \\
\text { - Consider withholding bosutinib, dose reductions or discontinuations } \\
\text { - For grade } 3-4 \text { diarrhea ( } \geq 7 \text { stools/day versus baseline/pre-treatment), withhold bosutinib until recovery to } \\
\text { grade } \leq 1 \text {, then resume at } 400 \mathrm{mg} \text { QD }\end{array}$ \\
\hline $\begin{array}{l}\text { Myelosuppression: } \\
\text { - Neutropenia } \\
\text { - Thrombocytopenia }\end{array}$ & $\begin{array}{l}\text { - Regular blood monitoring weekly for the first month of therapy and then monthly thereafter, or as clinically } \\
\text { indicated } \\
\text { - Advise patients to report any possible signs or symptoms as soon as possible, e.g., fever, signs of infection, easy } \\
\text { bruising, unexpected bleeding or blood in urine or stool } \\
\text { - Consider withholding bosutinib, dose adjustments or interruptions } \\
\text { - Concomitant administration of growth factors for resistant neutropenia and thrombocytopenia } \\
\text { For ANC less than } 1000 \times 10^{6} / \mathrm{I} \text { or platelets less than } 50,000 \times 10^{6} / \mathrm{l} \text { : } \\
\text { - Withhold bosutinib until ANC } \geq 1000 \times 10^{6} / \mathrm{I} \text { and platelets } \geq 50,000 \times 10^{6} / \mathrm{I} \\
\text { - Resume treatment with bosutinib at the same dose if recovery occurs within } 2 \text { weeks. If blood counts remain low } \\
\text { for }>2 \text { weeks, upon recovery, reduce dose by } 100 \mathrm{mg} \text { and resume treatment } \\
\text { - If cytopenia recurs, reduce dose by an additional } 100 \mathrm{mg} \text { upon recovery and resume treatment }\end{array}$ \\
\hline $\begin{array}{l}\text { Elevated liver function tests: } \\
\text { - ALT increased } \\
\text { - AST increased }\end{array}$ & $\begin{array}{l}\text { - Monitor liver enzymes at least monthly for the first } 3 \text { months, and where necessary } \\
\text { - Advise patients to report any possible signs or symptoms as soon as possible, e.g., 'tea-colored' urine or jaundice } \\
\text { - Avoid other hepatotoxic agents, where possible, and excessive consumption of alcohol } \\
\text { - No supportive care therapies; however, some clinical trials have used essential phospholipids, glycyrrhizic acid, milk } \\
\text { thistle extract, ursodiol, steroids and S-adenosylmethionine } \\
\text { - Consider withholding bosutinib, or dose reductions or discontinuations } \\
\text { - Increased transaminases }>5 \times \text { ULN: withhold bosutinib until } \leq 2.5 \times \text { ULN and resume at } 400 \mathrm{mg} \text { QD thereafter. If } \\
\text { recovery takes longer than } 4 \text { weeks, discontinue bosutinib treatment } \\
\text { - Increased transaminases } \geq 3 \times \text { ULN plus increased bilirubin }>2 \times \text { ULN and alkaline phosphatase }<2 \times \text { ULN: } \\
\text { discontinue bosutinib treatment }\end{array}$ \\
\hline $\begin{array}{l}\text { Dermatologic toxicities: } \\
\text { - Rash }\end{array}$ & $\begin{array}{l}\text { - Concomitant administration of hypoallergenic moisturizing creams, topical steroids, topical antiseptics, topical } \\
\text { antibiotics and/or antihistamines } \\
\text { - In severe cases, use systemic antibiotics and/or short-term systemic steroids } \\
\text { - Consider other potential causes for rash } \\
\text { - Consider consulting a dermatologist } \\
\text { - Avoid prolonged bathing, hot water when washing/showering and tight clothing } \\
\text { - Consider dose reductions and/or interruptions }\end{array}$ \\
\hline Fluid retention & $\begin{array}{l}\text { - Regular monitoring of signs and symptoms, and may manifest as pericardial effusion, pleural effusion, pulmonary } \\
\text { edema and/or peripheral edema } \\
\text { - Concomitant administration of diuretics and supportive care } \\
\text { - Consider withholding bosutinib, or dose reductions or discontinuations }\end{array}$ \\
\hline Renal dysfunction & $\begin{array}{l}\text { - Monitor renal function at baseline and during treatment with bosutinib } \\
\text { - Advise patients to report any possible signs or symptoms as soon as possible, e.g., changes in urinary frequency, } \\
\text { oliguria or polyuria } \\
\text { - Review of concomitant medications or other nephrotoxic agents } \\
\text { - Consider withholding bosutinib, or dose reductions or discontinuations - see Table } 3 \text { for renal impairment }\end{array}$ \\
\hline
\end{tabular}

medications prior to treatment selection and initiation is critical to mitigating the risk of developing treatmentemergent AEs. However, there are also a number of strategies to manage AEs that may arise during a therapy plan with bosutinib (Table 4), the most important is the availability of a clinic dedicated to CML [75].

One of the most common side effects with bosutinib treatment is gastrointestinal AEs, such as diarrhea, nausea and vomiting. Median time to onset of diarrhea was $2-3$ days and median duration of diarrhea was $2-3$ days [17,18]. Pharmacologic strategies include supportive care with anti-diarrheal, anti-emetic or anti-nausea medications; bosutinib dose reductions or interruptions; and avoidance of concomitant use with PPIs $[3,17,18,65,70,74,76]$. Nonpharmacologic strategies to manage these AEs include taking bosutinib with food and water; eating smaller meals; keeping well hydrated, for example, sports drinks to replenish electrolytes, although care should be taken to consider the mineral content of these drinks, in other words, the levels of sodium chloride versus glucose; and avoiding certain foods and drinks, such as caffeine and spicy food, that may exacerbate these AEs. Ensuring that patients are educated in the identification and alleviation of these symptoms and are provided dietary advice prior to and throughout bosutinib treatment are important for managing these gastrointestinal AEs $[3,17,18,65,70,74,76]$. 
Patient education is also critical to the management of treatment-emergent rash. Behavioral changes, for example, avoiding tight clothing and prolonged exposure to hot water and baths, are important nonpharmacologic strategies for dermatologic toxicities $[3,17,18,65,70,74,76]$. In addition to bosutinib dose modifications, patients can be administered supportive care therapies, such as hypoallergenic moisturizing creams, topical steroids, topical antiseptics, topical antibiotics and/or antihistamines. In severe cases, consultation with a dermatologist or administration of systemic antibiotics and/or short-term systemic steroids could be considered for treatment-emergent rash $[3,17,18,65,70,74,76]$.

Regular monitoring and patient reporting of signs and symptoms are critical to identifying treatment-emergent myelosuppression and/or elevated serum transaminases - both of which have been reported during treatment with bosutinib $[3,17,18,65,70,74,76$. Bosutinib dose modifications or interruptions in line with the product label is one of the most common treatment strategies to manage these AEs; however, these AEs have also been reported to spontaneously improve or return to normal after a few weeks $[3,17,18,65,70,74,76]$. Therefore, periodic assessment of and communication with the patient is important to identify and manage these treatment-emergent AEs, particularly in the first few months after initiating bosutinib therapy.

Other AE management strategies include monitoring renal function at baseline and throughout bosutinib treatment for signs of renal dysfunction, and the use of concomitant diuretics and supportive care for the treatment of fluid retention. As in all cases of treatment-emergent AEs, bosutinib dose reductions or interruptions should also be considered, where necessary $[3,17,18,65,70,74,76]$.

\section{Intensive management of $\mathrm{CML}$}

In line with European Leukemia Net (ELN) and National Comprehensive Cancer Network (NCCN) guidelines, regular monitoring of response is essential to the achievement of therapeutic milestones and the management of CML [3,4]. Achievement of early molecular responses during first-line treatment is indicative of long-term survival and positive clinical outcomes [2-4,9,72,73,77-82]. In the BELA trial, early response (BCR-ABL1/ABL1 $\leq 10 \%$ at 3 months) was associated with better CCyR by and MMR rates at 12 and 24 months in patients treated with first-line bosutinib or imatinib [34]. In the Phase I/II trial, early attainment or maintenance of MCyR by month 3 in patients treated with second-line bosutinib was associated with better overall survival. In patients treated with bosutinib following failure of $\geq 2 \mathrm{TKI}$, association with long-term outcomes was borderline for MCyR by month 3, but significant for MCyR by months 6, 9 and 12 [77,78]. Most importantly, early and regular monitoring can lead to improved treatment adherence and management of side effects, as well as help to identify the most appropriate therapy for an individual patient $[2-4,9,72,73]$. Patients receiving $B C R-A B L 1$ TKIs can be readily assessed for potential drug-drug interactions and AEs, thus allowing dose modifications to be made earlier and/or coadministering supportive care or concomitant medications. Furthermore, periodic monitoring ensures that patients who are inadequately responding to first-line treatment can be identified, and steps can be taken to adjust their therapy plan appropriately $[2-4,9,72,73]$.

\section{BCR-ABL1 kinase domain mutational status}

In the second- and later-line setting, resistance to prior $B C R-A B L 1$ TKI therapy is a particularly important consideration in treatment selection $[3,4,58,66]$. Mutations in the $B C R-A B L 1$ kinase domain are a frequent cause of resistance to $B C R-A B L 1$ TKI therapy and all patients should undergo $B C R-A B L 1$ mutational profile testing in order to guide TKI selection. Patients harboring V299L, T315A and F317L/V/I/C mutations are resistant to dasatinib; therefore, nilotinib is a recommended TKI for these patients. Y253H, E255K/V and F359V/C/I mutations convey resistance to nilotinib, and so dasatinib is a recommended TKI in this subset of patients. It is also recommended that patients harboring G250A, Y253H, E255K/V, F359V/C/I, T315A and F317L/V/I/C mutations be treated with bosutinib. However, a V299L mutation conveys resistance to bosutinib. Patients harboring T315I mutations should be treated with ponatinib, as this mutational profile is resistant to all other $B C R-A B L 1$ TKIs $[3,4,58,66]$.

\section{Other considerations for treatment selection}

Additional considerations for treatment selection in patients with CML include the impact of treatment adherence on clinical outcomes, for example, nonadherence to treatment has been associated with poorer response rates, deteriorations in quality of life and increased healthcare costs [56,58,72,83-87]. Factors that contribute to a lack of adherence to medication include AEs, drug-drug interactions and a lack of patient support and education. Therefore, it is critical to patient adherence that patients are prescribed the optimum $B C R-A B L$ TKI based on 
medical history, risk factors, pre-existing comorbidities and concomitant medications, as well as have regular monitoring and communications regarding AEs, continued assessment of the treatment plan, and ongoing patient education $[56,58,72]$.

Allogenic HSCT is a potentially curative option in patients with CML resistant or intolerant to all $B C R-A B L 1$ TKIs or BP CML, or who had progressed to AP or BP during BCR-ABL1 TKI treatment $[3,4,66]$. Existing evidence has shown that $B C R-A B L 1$ TKIs do not impact outcomes post allogenic HSCT or lead to an increase in transplantrelated toxicity [3]. Additionally, $B C R-A B L 1$ TKI monotherapy or in combination with chemotherapy could be considered for patients who are not candidates for transplant, or as a bridge and debulking option prior to allogenic HSCT [66].

\section{Dose optimization of bosutinib in the treatment of CML}

Following the selection of a $B C R-A B L 1$ TKI for the treatment of CML, it is important that patients are regularly and closely monitored to ensure that they are achieving the required therapeutic milestones, and that they are receiving appropriate supportive care for any treatment-emergent AEs, drug-drug interactions or worsening of comorbidities or quality of life $[3,4]$. Another consideration that is central to the management of CML is dose optimization of $B C R-A B L 1$ TKIs.

Per the product label, patients can initiate bosutinib at starting doses at less than the recommended dose in the case of comorbidities, such as hepatic and renal impairment $[17,18]$. The aim is to incrementally increase the bosutinib dose to the standard dose for the indication, where possible, and depending on patient tolerability [76]. In patients with suboptimal cytogenetic, hematologic or molecular response, and who do not have any grade 3 or higher AEs, incremental bosutinib dose escalations up to $600 \mathrm{mg}$ QD are permitted [17,18]. In the first-line setting, bosutinib dose escalations due to suboptimal response occurred in approximately $20 \%$ of patients in the BFORE trial (starting dose $400 \mathrm{mg} \mathrm{QD}$ ) and in $<10 \%$ of patients in the BELA trial (starting dose $500 \mathrm{mg}$ QD) [30-35].

In order to manage treatment-emergent AEs, bosutinib dose can be reduced and interrupted per the product label, and then resumed either at the starting dose or lower upon resolution of the $\mathrm{AE}$ [17,18]. In patients with newly diagnosed CP CML in the BFORE trial, bosutinib dose reduction down to 300 or $200 \mathrm{mg}$ QD improved tolerability and enabled patients to continue treatment [88]. A secondary analyses of the first-line BFORE and second-/later-line Phase I/II trial demonstrated that patients who had their dose reduced due to AEs were still able to achieve and/or maintain cytogenetic responses, even with bosutinib $200 \mathrm{mg}$ QD, and appeared to experience fewer gastrointestinal AEs $[76,88,89]$. In the BYOND study in patients with CP CML resistant or intolerant to prior TKIs, bosutinib dose reduction improved tolerability [90]. In the same study, patients who were TKI-resistant generally tolerated higher doses of bosutinib than TKI-intolerant patients. Additionally, individualized treatment allowed patients to remain on bosutinib and manage treatment-emergent AEs while maintaining efficacy, with some patients achieving a first response after dose reduction [90].

Long-term treatment plans will vary depending on patient age, as older patients may be more likely to present with comorbidities and concomitant medications, and younger patients may be more focused on achieving treatmentfree remission [56]. Therefore, optimization of bosutinib dose is an important aspect of ongoing and long-term CML management and can be individualized depending on the patient's medical circumstances and treatment preferences. Dose adjustments are also important for patient adherence to treatment, and thus will have a positive impact on clinical outcomes, quality of life and healthcare costs [56,58,72,83-87].

\section{Conclusion \& future perspective}

The availability of several $B C R-A B L 1$ TKI options for patients with CML means that physicians and patients can select the most appropriate treatment for an individual patient. Second-generation BCR-ABL1 TKIs have been compared with imatinib in clinical trials; however, further studies are needed to directly compare bosutinib, dasatinib and nilotinib. Bosutinib is a suitable treatment option for both patients with newly diagnosed (i.e., first-line) CML and those with CML resistant or intolerant to prior (i.e., second-line) therapies. Bosutinib has fewer severe AEs than other $B C R-A B L 1$ TKIs, such as nilotinib and dasatinib, while maintaining similar anti-leukemic efficacy, as well as activity against CML with dasatinib- and nilotinib-resistant mutations. However, the selection of bosutinib as a first- or later-line therapy is dependent on a number of factors, such as patient comorbidities, concomitant medications and risk factors. Additional information is needed to establish those patient subgroups that would benefit most from treatment with bosutinib, as well as the optimum bosutinib doses for patient subgroups. This is particularly important for long-term efficacy and safety outcomes. Regular monitoring of patients and patient 
education are key aspects of long-term CML management and contribute to improved clinical outcomes, quality of life, patient adherence and healthcare costs. Finally, treatment-free remission is becoming an increasing possibility in patients with CML and further studies are warranted to establish if particular patient subgroups and $B C R-A B L 1$ TKI combinations would lead to an increased likelihood and maintenance of treatment-free remission.

\section{Executive summary}

\section{Introduction to chronic myeloid leukemia}

- $B C R-A B L 1$-targeting tyrosine kinase inhibitors (TKIs) have revolutionized the treatment of chronic myeloid leukemia (CML).

- Current $B C R-A B L 1$ TKI treatment options for CML are imatinib, dasatinib, nilotinib, ponatinib and bosutinib.

Introduction to bosutinib

- Bosutinib exhibited dose proportional pharmacokinetics over the oral dose range of 200-800 mg.

- Bosutinib is primarily metabolized by cytochrome P450 3A4.

Bosutinib as a first-line option for the treatment of CML

- Bosutinib $400 \mathrm{mg}$ once daily (QD) is approved for patients with newly diagnosed chronic phase (CP) Philadelphia chromosome positive $(\mathrm{Ph}+) \mathrm{CML}$.

- In the BFORE trial, significantly higher rates of major molecular response (MMR) and complete cytogenetic response (CCyR) were observed for bosutinib $400 \mathrm{mg}$ QD versus imatinib $400 \mathrm{mg}$ QD.

- In the BELA trial, CCYR at 12 months was not met with bosutinib, despite a higher MMR rate, faster times to CCyR and MMR, and fewer on-treatment transformations to accelerated phase (AP)/blast phase (BP) with bosutinib $500 \mathrm{mg}$ QD versus imatinib $400 \mathrm{mg}$ QD.

- In both the BFORE and BELA trials, the safety profile of bosutinib was consistent with previous reports.

Bosutinib in the setting of second- \& later-line CML treatment

- Bosutinib $500 \mathrm{mg}$ QD is approved for patients with CP, AP or BP Ph+ CML resistant/intolerant to prior therapy.

- In a Phase I/II open-label trial, bosutinib 500 mg QD demonstrated durable efficacy and had a manageable safety profile for up to 5 years in patients with imatinib-resistant/intolerant CML.

- In the BYOND trial, bosutinib $500 \mathrm{mg}$ QD showed high rates of cytogenetic and molecular responses, including in a large proportion of patients who achieved deep molecular responses.

- In both the Phase I/II trial and BYOND, treatment with bosutinib was tolerable and manageable.

General considerations for bosutinib treatment selection in $\mathrm{CML}$

- Key considerations for bosutinib treatment selection include patient medical history, disease risk, comorbidities and concomitant medications.

- Effective adverse event (AE) monitoring and management can lead to improvements in clinical outcomes, quality of life and treatment adherence.

- Strategies for managing AEs include regular monitoring, supportive care, dose reductions and patient education.

- Additional considerations include early response monitoring and mutational status.

Dose optimization of bosutinib in the treatment of $\mathrm{CML}$

- Patients can initiate bosutinib at starting doses less than the recommended dose in cases of certain comorbidities.

- Bosutinib dose can be escalated incrementally in patients with suboptimal response.

- Bosutinib dose can be reduced to improve tolerability and to manage AEs, without a loss in efficacy.

Author contributions

All authors participated equally in discussions and development of the manuscript, contributed to correcting the draft manuscript, provided additional recommendations and have read and approved the final manuscript.

Financial \& competing interests disclosure

Pfizer provided a formal review of the publication, including for medical accuracy, but the authors had final authority on all aspects of content development. C Gambacorti-Passerini: consultancy (Bristol-Myers Squibb) and honoraria and research funding (Pfizer). P le Coutre: honoraria (ARIAD, Bristol-Myers Squibb, Incyte, Novartis, Pfizer) and research funding (Novartis). The authors have no other relevant affiliations or financial involvement with any organization or entity with a financial interest in or financial conflict with the subject matter or materials discussed in the manuscript apart from those disclosed.

Medical writing support was provided by Anne Marie McGonigal, PhD, at Engage Scientific Solutions and was funded by Pfizer.

Open access

This work is licensed under the Attribution-NonCommercial-NoDerivatives 4.0 Unported License. To view a copy of this license, visit http://creativecommons.org/licenses/by-nc-nd/4.0/ 


\section{References}

Papers of special note have been highlighted as: $\bullet$ of interest

1. National Cancer Institute. Cancer Stat Facts: leukemia - chronic myeloid leukemia (CML). (2018). https://seer.cancer.gov/statfacts/html/cmyl.html

2. Jabbour E, Kantarjian H. Chronic myeloid leukemia: 2018 update on diagnosis, therapy and monitoring. Am. J. Hematol. 93(3), 442-459 (2018).

3. National Comprehensive Cancer Network. NCCN Clinical Practice Guidelines in Oncology: chronic myeloid leukemia (2018). https://www.nccn.org/professionals/physician_gls/pdf/cml.pdf

4. Baccarani M, Deininger MW, Rosti G et al. European LeukemiaNet recommendations for the management of chronic myeloid leukemia: 2013. Blood. 122(6), 872-884 (2013).

5. Sasaki K, Strom SS, O'Brien S et al. Relative survival in patients with chronic-phase chronic myeloid leukaemia in the tyrosine-kinase inhibitor era: analysis of patient data from six prospective clinical trials. Lancet Haematol. 2(5), e186-193 (2015).

6. Rebora P, Czene K, Antolini L, Gambacorti Passerini C, Reilly M, Valsecchi MG. Are chronic myeloid leukemia patients more at risk for second malignancies? A population-based study. Am. J. Epidemiol. 172(9), 1028-1033 (2010).

7. Pophali PA, Patnaik MM. The role of new tyrosine kinase inhibitors in chronic myeloid leukemia. Cancer J. 22(1), 40-50 (2016).

8. Shah NP. Front-line treatment options for chronic-phase chronic myeloid leukemia. J. Clin. Oncol. 36(3), 220-224 (2018).

9. Kennedy JA, Hobbs G. Tyrosine kinase inhibitors in the treatment of chronic-phase CML: strategies for frontline decision-making. Curr. Hematol. Malig. Rep. 13(3), 202-211 (2018).

10. Kantarjian H, Sawyers $\mathrm{C}$, Hochhaus A et al. Hematologic and cytogenetic responses to imatinib mesylate in chronic myelogenous leukemia. N. Engl. J. Med. 346(9), 645-652 (2002).

11. Novartis. Gleevec (imatinib mesylate) prescribing information (2018). www.accessdata.fda.gov/drugsatfda_docs/label/2018/021588s053lbl.pdf

12. European Medicines Agency. Summary of product characteristics: imatinib medac (2018) www.ema.europa.eu/documents/product-information/imatinib-medac-epar-product-information_en.pdf

13. European Medicines Agency. Summary of product characteristics: sprycel (dasatinib) (2016). www.ema.europa.eu/documents/product-information/sprycel-epar-product-information_en.pdf

14. Bristol-Myers Squibb Co. Sprycel (dasatinib) prescribing information (2010). www.accessdata.fda.gov/drugsatfda_docs/label/2010/021986s7s8lbl.pdf

15. Novartis. Tasigna (nilotinib) prescribing information (2010). www.accessdata.fda.gov/drugsatfda_docs/label/2010/022068s004s005lbl.pdf

16. European Medicines Agency. Summary of product characteristics: tasigna (nilotinib) (2019). www.ema.europa.eu/documents/product-information/tasigna-epar-product-information_en.pdf

17. European Medicines Agency. Summary of product characteristics: bosulif (bosutinib) (2018). www.ema.europa.eu/documents/product-information/bosulif-epar-product-information_en.pdf

18. Pfizer Inc. Bosulif (bosutinib) prescribing information (2017). www.accessdata.fda.gov/drugsatfda_docs/label/2017/203341s009lbl.pdf

19. ARIAD Pharmaceuticals. Iclusig (ponatinib) prescribing information (2012). www.accessdata.fda.gov/drugsatfda_docs/label/2012/203469lbl.pdf

20. European Medicines Agency. Summary of product characteristics: Iclusig (ponatinib) (2019). www.ema.europa.eu/en/documents/product-information/iclusig-epar-product-information_en.pdf

21. Bower H, Björkholm M, Dickman PW, Höglund M, Lambert PC, Andersson TML. Life expectancy of patients with chronic myeloid leukemia approaches the life expectancy of the general population. J. Clin. Oncol. 34(24), 2851-2857 (2016).

22. Gambacorti-Passerini C, Antolini L, Mahon FX et al. Multicenter independent assessment of outcomes in chronic myeloid leukemia patients treated with imatinib. J. Natl Cancer Inst. 103(7), 553-561 (2011).

23. Amsberg GK, Koschmieder S. Profile of bosutinib and its clinical potential in the treatment of chronic myeloid leukemia. Onco. Targets Ther. 6, 99-106 (2013).

24. Puttini M, Coluccia AM, Boschelli F et al. In vitro and in vivo activity of SKI-606, a novel Src-Abl inhibitor, against imatinib-resistant Bcr-Abl+ neoplastic cells. Cancer Res. 66(23), 11314-11322 (2006).

25. Remsing Rix LL, Rix U, Colinge J et al. Global target profile of the kinase inhibitor bosutinib in primary chronic myeloid leukemia cells. Leukemia. 23(3), 477-485 (2009).

26. Golas JM, Arndt K, Etienne C et al. SKI-606, a 4-anilino-3-quinolinecarbonitrile dual inhibitor of Src and Abl kinases, is a potent antiproliferative agent against chronic myelogenous leukemia cells in culture and causes regression of K562 xenografts in nude mice. Cancer Res. 63(2), 375-381 (2003). 
27. Levinson NM, Boxer SG. Structural and spectroscopic analysis of the kinase inhibitor bosutinib and an isomer of bosutinib binding to the Abl tyrosine kinase domain. PLoS ONE 7(4), e29828 (2012).

28. Abbas R, Hug BA, Leister C, Gaaloul ME, Chalon S, Sonnichsen D. A Phase I ascending single-dose study of the safety, tolerability, and pharmacokinetics of bosutinib (SKI-606) in healthy adult subjects. Cancer Chemother. Pharmacol. 69(1), 221-227 (2012).

29. Abbas R, Hsyu PH. Clinical pharmacokinetics and pharmacodynamics of bosutinib. Clin. Pharmacokinet. 55(10), 1191-1204 (2016).

30. Cortes JE, Gambacorti-Passerini C, Deininger MW et al. Bosutinib versus imatinib for newly diagnosed chronic myeloid leukemia: results from the randomized BFORE trial. J. Clin. Oncol. 36(3), 231-237 (2018).

- Publishes the first results from the pivotal Phase III trial of bosutinib $400 \mathrm{mg}$ once daily (QD) versus imatinib $400 \mathrm{mg}$ QD in the first-line setting.

31. Cortes JE, Mauro MJ, Deininger MW et al. Bosutinib vs imatinib for newly diagnosed chronic myeloid leukemia in the BFORE trial: 24-month follow-up. In: 54th Annual Meeting of the American Society of Clinical Oncology (ASCO). IL, USA (2018).

32. Cortes JE, Kim DW, Kantarjian HM et al. Bosutinib versus imatinib in newly diagnosed chronic-phase chronic myeloid leukemia: results from the BELA trial. J. Clin. Oncol. 30(28), 3486-3492 (2012).

- Publishes the first results from the pivotal Phase III trial of bosutinib $500 \mathrm{mg}$ QD versus imatinib $400 \mathrm{mg}$ QD in the first-line setting.

33. Gambacorti-Passerini C, Cortes JE, Lipton JH et al. Safety of bosutinib versus imatinib in the Phase 3 BELA trial in newly diagnosed chronic phase chronic myeloid leukemia. Am. J. Hematol. 89(10), 947-953 (2014).

- Focuses on the safety data from the pivotal Phase III trial of bosutinib $500 \mathrm{mg}$ QD versus imatinib $400 \mathrm{mg}$ QD in the first-line setting.

34. Brümmendorf TH, Cortes JE, de Souza CA et al. Bosutinib versus imatinib in newly diagnosed chronic-phase chronic myeloid leukaemia: results from the 24-month follow-up of the BELA trial. Br. J. Haematol. 168(1), 69-81 (2015).

- Provides updated results from the pivotal Phase III trial of bosutinib $500 \mathrm{mg}$ QD versus imatinib $400 \mathrm{mg}$ QD in the first-line setting.

35. Gambacorti-Passerini C, Cortes JE, Harris P, Powell C, Countouriotis A, Kantarjian HM. Safety and management of toxicities in the BELA trial of bosutinib versus imatinib in newly diagnosed chronic phase chronic myeloid leukemia. Blood. 118(21), 1685 (2011).

36. O'Brien SG, Guilhot F, Larson RA et al. Imatinib compared with interferon and low-dose cytarabine for newly diagnosed chronic-phase chronic myeloid leukemia. N. Engl. J. Med. 348(11), 994-1004 (2003).

37. Hochhaus A, Larson RA, Guilhot F et al. Long-term outcomes of imatinib treatment for chronic myeloid leukemia. N. Engl. J. Med. 376(10), 917-927 (2017).

38. Kantarjian H, Shah NP, Hochhaus A et al. Dasatinib versus imatinib in newly diagnosed chronic-phase chronic myeloid leukemia. $N$. Engl. J. Med. 362(24), 2260-2270 (2010).

39. Cortes JE, Saglio G, Kantarjian HM et al. Final 5-year study results of DASISION: the dasatinib versus imatinib study in treatment-naive chronic myeloid leukemia patients trial. J. Clin. Oncol. 34(20), 2333-2340 (2016).

40. Saglio G, Kim DW, Issaragrisil S et al. Nilotinib versus imatinib for newly diagnosed chronic myeloid leukemia. N. Engl. J. Med. 362(24), 2251-2259 (2010).

41. Hochhaus A, Saglio G, Hughes TP et al. Long-term benefits and risks of frontline nilotinib vs imatinib for chronic myeloid leukemia in chronic phase: 5-year update of the randomized ENESTnd trial. Leukemia 30(5), 1044-1054 (2016).

42. Gambacorti-Passerini C, Cortes JE, Lipton JH et al. Safety and efficacy of second-line bosutinib for chronic phase chronic myeloid leukemia over a five-year period: final results of a Phase I/II study. Haematologica 103(8), 1298-1307 (2018).

- Provides the updated and final analyses from the Phase I/II trial of bosutinib $500 \mathrm{mg}$ QD in patients with imatinib-resistant or -intolerant hronic myeloid leukemia (CML).

43. Cortes JE, Khoury HJ, Kantarjian HM et al. Long-term bosutinib for chronic phase chronic myeloid leukemia after failure of imatinib plus dasatinib and/or nilotinib. Am. J. Hematol. 91(12), 1206-1214 (2016).

44. Whiteley J, Reisman A, Shapiro M, Cortes J, Cella D. Health-related quality of life during bosutinib (SKI-606) therapy in patients with advanced chronic myeloid leukemia after imatinib failure. Curr. Med. Res. Opin. 32(8), 1325-1334 (2016).

45. Brümmendorf TH, Cortes JE, Khoury HJ et al. Factors influencing long-term efficacy and tolerability of bosutinib in chronic phase chronic myeloid leukaemia resistant or intolerant to imatinib. Br. J. Haematol. 172(1), 97-110 (2016).

46. Khoury HJ, Cortes JE, Kantarjian HM et al. Bosutinib is active in chronic phase chronic myeloid leukemia after imatinib and dasatinib and/or nilotinib therapy failure. Blood 119(15), 3403-3412 (2012).

- Focuses on the use of bosutinib after multiple TKI failure in the Phase I/II trial of bosutinib $500 \mathrm{mg}$ QD in patients with imatinib-resistant or -intolerant CML.

47. Cortes JE, Kantarjian HM, Brümmendorf TH et al. Safety and efficacy of bosutinib (SKI-606) in chronic phase Philadelphia chromosome-positive chronic myeloid leukemia patients with resistance or intolerance to imatinib. Blood. 118(17), $4567-4576$ (2011). 
- Publishes the first results from the the Phase I/II trial of bosutinib $500 \mathrm{mg}$ QD in patients with imatinib-resistant or -intolerant CML.

48. Gambacorti-Passerini C, Abboud CN, Gjertsen BT et al. Primary results of the Phase 4 BYOND study of bosutinib (BOS) for pretreated chronic phase (CP) chronic myeloid leukemia (CML). J. Clin. Oncol. 37(Suppl. 15), 7012-7012 (2019).

49. Shah NP, Rousselot P, Schiffer C et al. Dasatinib in imatinib-resistant or -intolerant chronic-phase, chronic myeloid leukemia patients: 7-year follow-up of study CA180-034. Am. J. Hematol. 91(9), 869-874 (2016).

50. Giles FJ, le Coutre PD, Pinilla-Ibarz J et al. Nilotinib in imatinib-resistant or imatinib-intolerant patients with chronic myeloid leukemia in chronic phase: 48-month follow-up results of a Phase II study. Leukemia 27(1), 107-112 (2013).

51. Cortes JE, Kim DW, Pinilla-Ibarz J et al. Ponatinib efficacy and safety in Philadelphia chromosome-positive leukemia: final 5-year results of the Phase 2 PACE trial. Blood 132(4), 393-404 (2018).

52. Cortes JE, Muresan B, Mamolo C et al. Matching-adjusted indirect comparison of bosutinib, dasatinib and nilotinib effect on survival and major cytogenetic response in treatment of second-line chronic phase chronic myeloid leukemia. Curr. Med. Res. Opin. 35(9), 1615-1622 (2019).

53. Hu B, Savani BN. Impact of risk score calculations in choosing front-line tyrosine kinase inhibitors for patients with newly diagnosed chronic myeloid leukemia in the chronic phase. Eur. J. Haematol. 35(9), 179-186 (2014).

54. Hasford J, Pfirrmann M, Hehlmann R et al. A new prognostic score for survival of patients with chronic myeloid leukemia treated with interferon alfa. Writing Committee for the Collaborative CML Prognostic Factors Project Group. J. Natl Cancer Inst. 90(11), 850-858 (1998).

55. Sokal JE, Cox EB, Baccarani M et al. Prognostic discrimination in "good-risk" chronic granulocytic leukemia. Blood 63(4), 789-799 (1984).

56. Saglio G, Jabbour E. First-line therapy for chronic phase CML: selecting the optimal BCR-ABL1-targeted TKI. Leuk. Lymphoma 59(7), 1523-1538 (2018).

57. Gambacorti-Passerinin C, le Coutre P. [CML]. In: DeVita, Hellman, and Rosenberg's Cancer: Principles \& Practices of Oncology, 11 th ed. De Vita VT, Lawrence TS, Rosenburg SA (Eds). Wolters Kluwer Health/Lippincott Williams and Wilkins, PA, USA, 2432 (2018).

58. Cuellar S, Vozniak M, Rhodes J, Forcello N, Olszta D. BCR-ABL1 tyrosine kinase inhibitors for the treatment of chronic myeloid leukemia. J. Oncol. Pharm. Pract. 24(6), 433-452 (2018).

59. Gugliotta G, Castagnetti F, Fogli M, Cavo M, Baccarani M, Rosti G. Impact of comorbidities on the treatment of chronic myeloid leukemia with tyrosine-kinase inhibitors. Expert Rev. Hematol. 6(5), 563-574 (2013).

60. Medeiros BC, Possick J, Fradley M. Cardiovascular, pulmonary, and metabolic toxicities complicating tyrosine kinase inhibitor therapy in chronic myeloid leukemia: strategies for monitoring, detecting, and managing. Blood Rev. 32(4), 289-299 (2018).

61. Saussele S, Krauss MP, Hehlmann R et al. Impact of comorbidities on overall survival in patients with chronic myeloid leukemia: results of the randomized CML study IV. Blood 126(1), 42-49 (2015).

62. Aghel N, Delgado DH, Lipton JH. Cardiovascular toxicities of BCR-ABL tyrosine kinase inhibitors in chronic myeloid leukemia: preventive strategies and cardiovascular surveillance. Vasc. Health Risk Manag. 13, 293-303 (2017).

63. Isfort S, Brümmendorf TH. Bosutinib in chronic myeloid leukemia: patient selection and perspectives. J. Blood Med. 9 , 43-50 (2018).

64. Barber MC, Mauro MJ, Moslehi J. Cardiovascular care of patients with chronic myeloid leukemia (CML) on tyrosine kinase inhibitor (TKI) therapy. Hematology Am. Soc. Hematol. Educ. Program. 2017(1), 110-114 (2017).

65. Steegmann JL, Baccarani M, Breccia M et al. European LeukemiaNet recommendations for the management and avoidance of adverse events of treatment in chronic myeloid leukaemia. Leukemia 30(8), 1648-1671 (2016).

66. Hochhaus A, Saussele S, Rosti G et al. Chronic myeloid leukaemia: ESMO Clinical Practice Guidelines for diagnosis, treatment and follow-up. Ann. Oncol. 28(Suppl. 4), iv41-iv51 (2017).

67. Ross DM, Arthur C, Burbury K et al. Chronic myeloid leukaemia and tyrosine kinase inhibitor therapy: assessment and management of cardiovascular risk factors. Intern. Med. J. 48(Suppl. 2), 5-13 (2018).

68. Cortes JE, Gambacorti-Passerini C, Kim DW et al. Effects of bosutinib treatment on renal function in patients with Philadelphia chromosome-positive leukemias. Clin. Lymphoma Myeloma Leuk. 17(10), 684-695 (2017).

69. Cortes JE, Jean Khoury H, Kantarjian $\mathrm{H}$ et al. Long-term evaluation of cardiac and vascular toxicity in patients with Philadelphia chromosome-positive leukemias treated with bosutinib. Am. J. Hematol. 91(6), 606-616 (2016).

70. Khoury HJ, Gambacorti-Passerini C, Brümmendorf TH. Practical management of toxicities associated with bosutinib in patients with Philadelphia chromosome-positive chronic myeloid leukemia. Ann. Oncol. 29(3), 578-587 (2018).

- Provides an overview of adverse events associated with bosutinib and how they can be managed in clinical practice.

71. Cortes JE, Gambacorti-Passerini C, Deininger MW, Abruzzese E, DeAnnuntis L, Brümmendorf TH. Pregnancy outcomes in patients treated with bosutinib. Blood 132(Suppl. 1), 1729 (2018).

72. Bauer S, Buchanan S, Ryan I. Tyrosine kinase inhibitors for the treatment of chronic-phase chronic myeloid leukemia: long-term patient care and management. J. Adv. Pract. Oncol. 7(1), 42-54 (2016). 
73. Goldberg SL, Cortes JE, Gambacorti-Passerini C et al. First-line treatment selection and early monitoring patterns in chronic phase-chronic myeloid leukemia in routine clinical practice: SIMPLICITY. Am. J. Hematol. 92(11), 1214-1223 (2017).

74. Ault PS, Rose J, Nodzon LA, Kaled ES. Bosutinib therapy in patients with chronic myeloid leukemia: practical considerations for management of side effects. J. Adv. Pract. Oncol. 7(2), 160-175 (2016).

75. Gambacorti-Passerini C, Piazza R. How I treat newly diagnosed chronic myeloid leukemia in 2015. Am. J. Hematol. 90(2), 156-161 (2015)

76. Cortes JE, Apperley JF, DeAngelo DJ et al. Management of adverse events associated with bosutinib treatment of chronic-phase chronic myeloid leukemia: expert panel review. J. Hematol. Oncol. 11(1), 143 (2018).

- Of interest.

77. Cortes JE, Brümmendorf TH, Khoury HJ et al. Assessment of early cytogenetic response as a predictor of long-term clinical outcomes in a Phase 1/2 study of bosutinib in chronic phase CML. Blood 120(21), 2798-2798 (2012).

78. Cortes JE, Brümmendorf TH, Khoury HJ et al. Assessment of early cytogenetic response as a predictor of long-term clinical outcomes in a Phase 1/2 study of bosutinib in chronic phase CML. Haematologica. 98(Suppl. 1), P148 (2013).

79. Jabbour E, Kantarjian HM, Saglio G et al. Early response with dasatinib or imatinib in chronic myeloid leukemia: 3-year follow-up from a randomized Phase 3 trial (DASISION). Blood 123(4), 494-500 (2014).

80. Hughes TP, Saglio G, Kantarjian HM et al. Early molecular response predicts outcomes in patients with chronic myeloid leukemia in chronic phase treated with frontline nilotinib or imatinib. Blood 123(9), 1353-1360 (2014).

81. Wang R, Cong Y, Li C, Zhang C, Lin H. Predictive value of early molecular response for deep molecular response in chronic phase of chronic myeloid leukemia. Medicine (Baltimore) 98(15), e15222 (2019).

82. Harrington P, Kizilors A, de Lavallade H. The role of early molecular response in the management of chronic phase CML. Curr. Hematol. Malig. Rep. 12(2), 79-84 (2017).

83. Okumura LM, Antunes VD, Aguiar KS, Farias T, Andrzejevski VM, Funke VM. Tyrosine kinase inhibitors in patients with chronic myelogeneous leukemia: defining the role of social risk factors and non-adherence to treatment. Pharm. Pract. (Granada) 13(2), 559 (2015).

84. Ganesan P, Sagar TG, Dubashi B et al. Nonadherence to imatinib adversely affects event free survival in chronic phase chronic myeloid leukemia. Am. J. Hematol. 86(6), 471-474 (2011).

85. Noens L, Hensen M, Kucmin-Bemelmans I, Lofgren C, Gilloteau I, Vrijens B. Measurement of adherence to BCR-ABL inhibitor therapy in chronic myeloid leukemia: current situation and future challenges. Haematologica 99(3), 437-447 (2014).

86. Ibrahim AR, Eliasson L, Apperley JF et al. Poor adherence is the main reason for loss of CCyR and imatinib failure for chronic myeloid leukemia patients on long-term therapy. Blood 117(14), 3733-3736 (2011).

87. Rychter A, Jerzmanowski P, Hołub A et al. Treatment adherence in chronic myeloid leukaemia patients receiving tyrosine kinase inhibitors. Med. Oncol. 34(6), 104 (2017).

88. Brümmendorf TH, Gambacorti-Passerini C, Hochhaus A et al. Efficacy and safety following dose reduction of bosutinib or imatinib in patients with newly diagnosed chronic myeloid leukemia: analysis of the Phase 3 BFORE trial. Blood 132(Suppl. 1), 3005 (2018).

89. Kota V, Brümmendorf TH, Gambacorti-Passerini C et al. Efficacy and safety following bosutinib dose reduction in patients with Philadelphia chromosome-positive chronic myeloid leukemia. Blood. 128(22), 1921 (2016).

90. Brümmendorf TH, Giles F, Gambacorti-Passerini C et al. Efficacy and safety following dose reduction of bosutinib in previously treated patients with chronic myeloid leukemia: Analysis of the Phase 4 BYOND trial. In: 24th congress of the European Hematology Association. Amsterdam, The Netherlands (2019). https:/library.ehaweb.org/eha/2019/24th/266215/tim.h.brmmendorf.efficacy.and.sa fety.following.dose.reduction.of.bosutinib.in.html?f=listing\%3D0\%2Abrowseby\%3D8\%2Asortby\%3D2\%2Asearch\%3Dtki 